\title{
BAZI SÖZCÜKLERİN ÇAĞRIŞIMSAL MANALARI: ANLAMSAL FARKLANDIRMA ÜZERINE BİR UYGULAMA
}

\author{
CONNOTATIVE MEANINGS OF SOME SIMILAR WORDS: AN \\ APPLICATION OF SEMANTIC DIFFERENTIAL
}

\section{АССОЦИАТИВНЫЕ ЗНАЧЕНИЙ НЕКОТОРЫХ СЛОВАРЕЙ: СМЫСЛОВЫЕ РАЗЛИЧИЯ И РАЗНОГЛАСИЯ ${ }^{1}$}

\author{
Hakan AYDOĞAN* \\ Mustafa ŞENEL ${ }^{* *}$
}

\begin{abstract}
ÖZ
Çağrışım ve düzanlam anlam bilimin önemli iki ana başlıklarıdır. Sözcüklerin çağrışımsal manaları sözde farklandırma teknikleri uygulayarak incelenebilirler. Bu da bize sözcüklerin duygusal manalarının yanısıra metaforik manalarını da tanımlamamızı ve onlar hakkında fikir yürütmemizi sağlar. Bu araştırmada, "mum", "mother", "home", "house", "man", ve "person" sözcüklerinin bu türden manaları çalışıldı. Zıt manalı sıfatlardan oluşan yedili likert ölçeği kullanılmıştır. Anket Saraybosna Üniversitesinde 21'inin erkek, 55'inin de kıların olduğu 76 öğrenci üzerinde uygulanmıştır. "mum" sözcüğü "mother" ile karşılaştırıldığında kulağa "daha genç, güçlü, güzel ve samimi" gelmektedir. "Home"sözcüğü "house" ile karşılaştırıldığında "daha sıcak, yumuşak, aktif, güzel, yakın ve belirgin anlaşılmaktadır. Çağrışımsal manalar göztergebilim ve anlambilimin ilginç konularıdır.
\end{abstract}

Anahtar Kelimeler: Anlamsal farklandırma tekniği, anlambilim, eşanlam, düzanlam, çağrışım.

\section{ABSTRACT}

Connotation and denotation are two important topics in semantics. Connotation of words can be examined by applying so-called semantic differential technique. It can help us to describe and estimate metaphorical as well as emotional meanings of words. In this study, we estimated the meaning of the following words: "mum", "mother", "home", "house", "man", and "person". We used a seven-point Likert scale, with ten pairs of opposites (adjectives). This scale was distributed among 76 students at the University of Sarajevo, where 21 of them were males and 55 were females. Our results pointed out the three following things. First, the word "mum" compared to the word "mother" sounds "younger", more "active", "stronger", more "beautiful", and "closer". The word "home" compared to the word "house" was somehow "hotter", "softer", more "active", more

${ }^{1}$ DOI : 10.17498/kdeniz.680

* Arş. Grv. Sitkı Koçman Üniversitesi,Marmaris,,Muğla, aydoganh@hotmail.com

${ }^{* *}$ Doç. Dr., Kafkas Üniversitesi, Fen-Edb.Fak. Türk Dili ve Edb. Böl., Kars, mustafasenel@hotmail.com 
"beautiful", "closer", and more "clear". Connotative meanings seem to be a very interesting subject of semiotics/semantics.

Key words:semantic differential technique, semantics, synonyms, denotation, connotation.

\section{АННОТАЦИЯ}

Ассоциативное прямое значение являються двумя важными понятиями в языкознании. Ассоциативные значения слов в словарях когут исследоваться при помощи методов, способствующих различению слов. Это дает возможность нам размышлять об эмоциональных смысловых наряду с метафорическими значениями слова, даннями в соварных статьях. В этом исследовании рассмотрены и раскрыты значений слов «тum», «mother», «home», «house», «man», «person», данных в разных словарях. Использована шкала Лайкерта из семи прилагательных с антонимичными парами. Анкетирование проводилось в Сарайбосна университете. В нем приняли участие 21 респондентов-мужчин, 55 респондентов-женщин, всего - 76 студентов. Анализ анкет показал различное понимание и объяснение смыслов сравниваемых слов. В итоге мы убедились в том, что ассоциативные значения слов в контексте внешних и внутренних пониманий являются очень интересной темой.

Ключевые слова: метод различения смыслов, семантика, синоним, прямое значение, ассоциация.

\section{Introduction}

Semantic differential is a technique which serves for examining the experience of different words. Participants differ in their emotional response to some words (especially nouns and adjectives) as well as in attributing connotative meanings to a presented word, concept, or term. Of course, there are some average tendencies and similarities between people, because some connotative meanings are common for a particular group of people.

In particular, semantic differential is used in the field of semantics, because this scientific area deals with denonative and connotative meanings of words. It is also a powerful tool in cognitive linguistics. Denotative meaning is the strict (literal) meaning of a word, which can be found in dictionaries of a language (e.g. Sternberg, 2012:375; Crystal, 1987:418). Connotative meanings are emotional, metaphorical, allegorical or indirect meanings of a word (e.g. Larson, 1984:80; Barthes, Lavers, \& Smith, 1967:90). For instance, "fox" is a word which refers to a wild animal (which is its denotative meaning), but we also use it to decribe someone who is cunning, shifty, and sly.

Snider and Osgood (1969:55) discovered that we can evaluate one word based on the three following dimensions (aspects): evaluation (e.g. as good or bad), activity (e.g. active/dynamic or passive/static), and potency (e.g. strong/powerful or weak). Furthermore, Osgood, Suci, and Tannenbaum (1957:342) stated that these dimensions are cross-cultural univerlsals.

Interestingly, people also have some "distant" associations and feelings about a particular word. It can be experienced as bitter or sweet, sharp or rounded, soft or solid/hard... We will give an example of it. Suppose participants are presented with a noun "father". Our fathers are usually firm, strong and unforgiving, unlike our mothers. Hence, participants will "experience" this word as "sharp", "strong", "powerful", and "bitter". 
Semantic differential is a set of rating scales and at the top of it we place a particular word (e.g. "politics", "TV", "school", "man", "classical music", "homosexuality", "family", etc.). These scales are of a bipolar type, and at their ends are two opposite adjectives (e.g. strong - weak, rough - gentle, pleasant - unpleasant, interesting - boring, easy - difficult, etc.). Between every pair of adjectives there is usually a five- or seven-point scale. It can be presented in the form of Likert scale (e.g. from 1 to 5 or from 1 to 7 ), or in the form of bipolar scale (e.g. -3 to +3 , or -2 to +2 ). In the first example, "3" and five respectively are considered as midpoints of these scales. In the last example, the value of "zero" is actually the average value (i.e. the midpoint of the scale). If participant "feels" that the presented word can be described better by using one of the adjectives, he picks the number on the scale which is closer to that adjective. There are several variations of semnatic differential forms: numeric, graphical, and verbal (Garland, 1990:20). In our research, we chosed the first one, because it is the most frequently used format of this technique.

Reviewing the literature in this field, we found several interesting applications of the semantic differential technique. Gargante, Meneses and Monereo (2013:9) used it to examine university professors' attitudes towards teaching. The triggering words (phrases) were as follows: "motivation for teaching", "evaluation of oneself as a teacher", and "performance of teaching". They used these pairs of adjectives: negative - positive, demanding - undemanding, hard - soft, complex - simple, tense - peaceful, superficial deep, incomplete - complete, inopportune - timely, heavy - light ... On the other side, Norbergh, Helin, Dahl, Hellzen, and Asplund (2006:264) examined nurses' attitudes towards people diagnosed with dementia. We will give some examples of the adjectives used in their study: calm - aggressive, reliable - unreliable, warm - cold, good - evil, significant - insignificant, joyful - sad, harmonious - desperate, valuable - valueless, cared for - rejected, and smooth - rough. Weed and Nicholson (2014:1) investigated social evaluation tendencies towards pregnant teens, teen mothers and fathers. Their semantic differential form consisted of the following pairs of adjectives: involved - uninvolved, mature - immature, moral - immoral, active - inactive, fun - boring, sensible - foolish, loving - hostile, warm - cold, etc.

Keller and her colleagues (2013:71) used it to compare US and German sample on their connotations regarding spirituality and religion. The emotional aspect of these two abstract terms is estimated by using the following pairs of opposites: awful - nice, little big, powerless - powerful, rough - smooth, hellish - heavenly, dirty -clean, empty - full, etc. First of all, their study revealed significant differences in perceiving and experiencing religion and spirituality. According to their participants, spirituality is nicer, more fine, more heavenly, cleaner, lighter, and milder than religion (in both of the samples). Further, US participants had slightly different feelings (compared with German participants). They think spirituality is nicer and cleaner whereas religion is lighter and more powerful. On the other side, German participants did not think spirituality is so nice and clean, neither religion is so light and powerful (Keller et al., 2013:94).

Despite liguists provided lots of examples of semantic differential technique, we could not find real empirical studies where this powerful technique is used in investigating specific topics in semiotics/semantics. Thus, our study can be seen as an attempt to promote this kind of technique and to show its usefulness in determining differences between words with more literate meaning and those which can trigger connotative meanings.

Hence, our research questions are defined as follows: 
1) Is there a difference between words "mother" and "mum" in their emotional tone?

2) Is there a difference between words "house" and "home" in their emotional aspect?

3) Shall we find a difference in emotional meaning of words "person" and "man"?

In accordance with our research questions, we proposed the following hypotheses:

1) The word "mum" is experienced as a significantly different term (with respect to its emotional component), compared to the word "mother".

2) The word "home" has significantly higher emotional tone than does the word "house".

3) Participants' feelings about the words "person" and "man" are significantly different.

Therefore, we examined and compared three pairs of synonyms, in order to investigate differences between their connotational meanings.

\section{Methodology}

Participants

Our sample consisted of 76 students from the University of Sarajevo (Bosnia and Herzegovina). There were 55 females $(72.4 \%)$ and 21 males $(27.6 \%)$, as it is displayed in Figure 1.

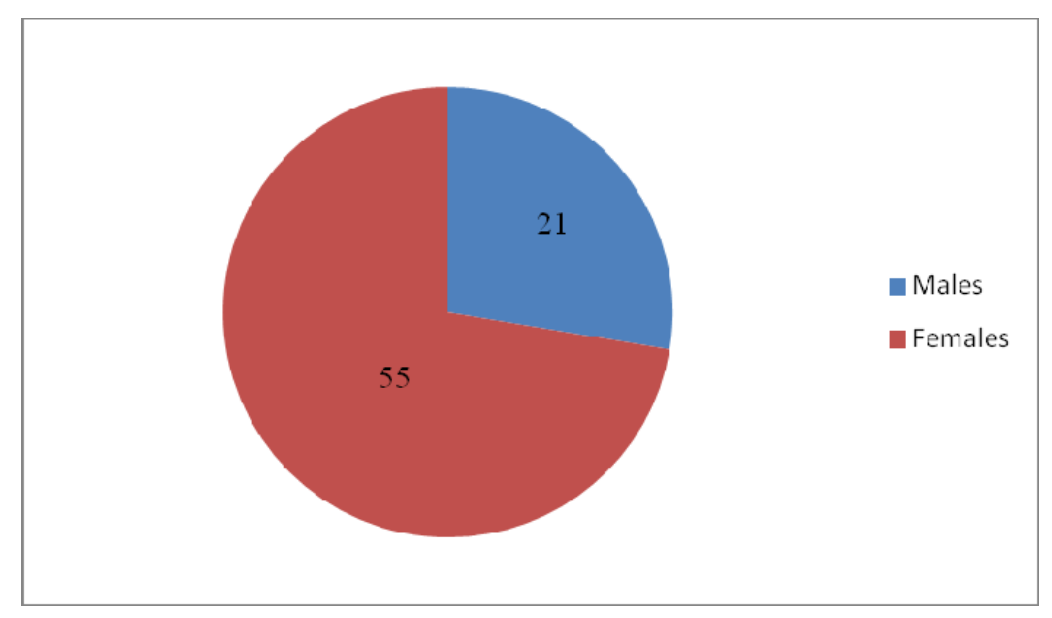

Figure 1. Gender distribution of the sample

All students were chosen based on their English language knowledge. Hence, all of them could understand the content of our survey. 


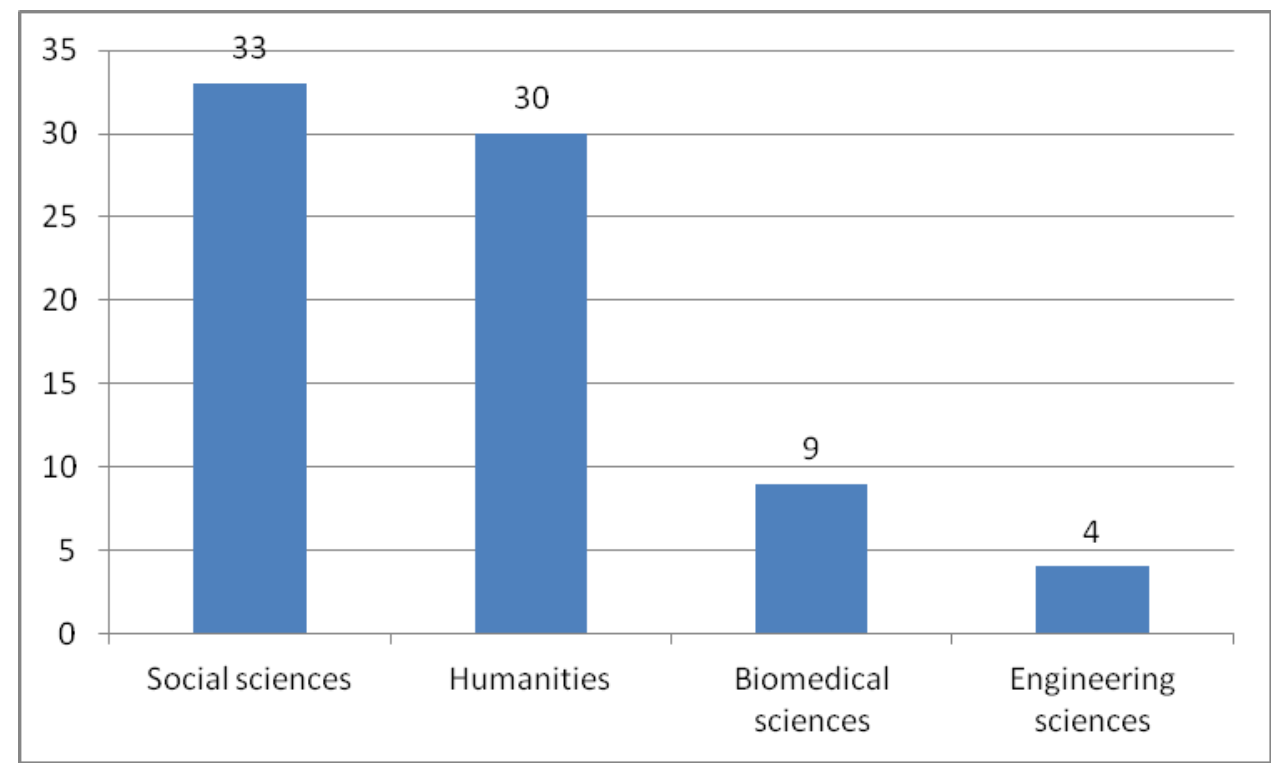

Figure 2. Studying programs of our participants

As can be seen in Figure 2, 33 of them (43.42\%) studied social sciences, 30 participants $(39.47 \%)$ studied humanities, nine of them $(11.84 \%)$ studied biomedical sciences, and four participants (5.26\%) studied engineering sciences. Participants' mean age was $\mathrm{M}=20.05$ and the standard deviation of their age was $\mathrm{SD}=0.85$.

\section{Instruments and procedure}

We designed a form of semantic differential where the following ten pairs of adjectives were included: cold - warm, old - young, soft - hard, active - passive, big - small, strong weak, beautiful - ugly, far away - close, bad - good, and clear - unclear (obscure). Next, we added a seven-point Likert scale to every pair of adjectives. Every participant was presented with six words: "mother", "mum", "house", home", "person", and "man" and their task was to estimate connotative meanings of these words with regard to ten aforementioned adjectives. It takes them approximately 10 minutes to fulfill this scales. We also have to mention that this study was conducted according to ethical principles and the respondents were guaranteed anonymity.

\section{Data processing}

The collected data were analyzed in MS Excel 2010 and SPSS for Win 16.0. We applied non-parametic statistical procedures. First, descriptive statistical values were calculated and after that we applied Wilcoxon's test of equivalent pairs. This test is used for examining differences between two sets of answers (scores) in the same sample of participants.

\section{Results}

We displayed descriptive statistical values in Table 1. Mdn is a label of median, which is a central value of a ranked set of data. IQR is the abbreviation of interquartile range, 
which represents the range where fall $50 \%$ of participants' scores (results). These scores fall around the median value of data.

Table 1. Descriptive statistical values

\begin{tabular}{|c|c|c|c|c|c|c|c|c|c|c|c|c|}
\hline \multirow{2}{*}{$\begin{array}{c}\text { Words } \\
\text { Adjectives }\end{array}$} & \multicolumn{2}{|c|}{ MUM } & \multicolumn{2}{|c|}{ MOTHER } & \multicolumn{2}{|c|}{ HOUSE } & \multicolumn{2}{|c|}{ HOME } & \multicolumn{2}{|c|}{ MAN } & \multicolumn{2}{|c|}{ PERSON } \\
\hline & Mdn & IQR & Mdn & IQR & Mdn & IQR & Mdn & IQR & Mdn & IQR & Mdn & IQR \\
\hline $\begin{array}{l}\text { Hot- } \\
\text { cold }\end{array}$ & 1 & 1 & 1 & 0.75 & 2 & 3 & 1 & 1 & 4 & 3 & 4 & 3 \\
\hline $\begin{array}{l}\text { Old- } \\
\text { young }\end{array}$ & 4 & 2 & 3 & 3 & 4 & 3 & 4 & 3 & 4 & 1 & 4 & 1.75 \\
\hline $\begin{array}{l}\text { Soft- } \\
\text { hard }\end{array}$ & 2 & 2 & 2 & 2 & 4 & 5 & 3 & 4 & 6 & 3 & 4 & 3 \\
\hline $\begin{array}{l}\text { Active- } \\
\text { passive }\end{array}$ & 2 & 2 & 3 & 5 & 4 & 4 & 4 & 3.5 & 2 & 3 & 3 & 3 \\
\hline $\begin{array}{l}\text { Big- } \\
\text { small }\end{array}$ & 3 & 4 & 4 & 4 & 3 & 3 & 2 & 3 & 3 & 3 & 4 & 3 \\
\hline $\begin{array}{c}\text { Strong- } \\
\text { weak }\end{array}$ & 3 & 4 & 4 & 5 & 2 & 3 & 2.5 & 3 & 1.5 & 1.75 & 3 & 4 \\
\hline $\begin{array}{c}\text { Beautiful- } \\
\text { ugly }\end{array}$ & 1 & 1 & 2 & 3 & 2 & 3 & 2 & 1.5 & 3 & 2 & 4 & 2.25 \\
\hline $\begin{array}{c}\text { Far away- } \\
\text { close }\end{array}$ & 6 & 3 & 5 & 4 & 5 & 3 & 6 & 3 & 4 & 3.25 & 4 & 2 \\
\hline $\begin{array}{l}\text { Bad- } \\
\text { good }\end{array}$ & 7 & 6 & 7 & 2 & 6 & 2 & 7 & 2.25 & 5 & 2 & 4 & 2 \\
\hline $\begin{array}{l}\text { Clear- } \\
\text { unclear }\end{array}$ & 3 & 6 & 3 & 3 & 4 & 2.5 & 2 & 3 & 4 & 2 & 5 & 3 \\
\hline
\end{tabular}

We can see (Table 1) that median values for pair of adjectives "old - young" in the case of words "mum" and "mother" are different (Mdn = 4 vs. Mdn = 3). If we consider pair of adjectives "far away - close", we can notice that participants (on average) said that they "feel" the concept "home" closer $(\mathrm{Mdn}=6)$ than the term "house" $(\mathrm{Mdn}=5)$.

In order to investigate whether there are significant differences, we conducted Wilcoxon's test. This is a non-parametric substitute of t-test for paired samples. The results are shown in Tables 2, 3, and 4.

Table 2. The results of comparisons between "mum" and "mother"

\begin{tabular}{ccccc}
\hline Pairs of adjectives & Comparisons & Number of ranks & $\mathrm{z}$ & $\mathrm{p}$ \\
\hline \multirow{3}{*}{ Hot-cold } & mother $<$ mum & 15 & & \\
& mother $>$ mum & 7 & -1.465 & .143 \\
& mother=mum & 54 & & \\
\hline \multirow{3}{*}{ Old-young } & mother $<$ mum & 41 & & \\
& mother $>$ mum & 9 & -4.096 & .000 \\
& mother=mum & 25 & & \\
\hline
\end{tabular}




\begin{tabular}{|c|c|c|c|c|}
\hline \multirow{3}{*}{ Soft-hard } & mother $<$ mum & 22 & \multirow{3}{*}{-1.752} & \multirow{3}{*}{.080} \\
\hline & mother $>$ mum & 17 & & \\
\hline & mother $=$ mum & 35 & & \\
\hline \multirow{3}{*}{ Active-passive } & mother $<$ mum & 5 & \multirow{3}{*}{-4.348} & \multirow{3}{*}{.000} \\
\hline & mother $>$ mum & 36 & & \\
\hline & mother $=$ mum & 31 & & \\
\hline \multirow{3}{*}{ Big-small } & mother $<$ mum & 19 & \multirow{3}{*}{-1.657} & \multirow{3}{*}{.098} \\
\hline & mother $>$ mum & 30 & & \\
\hline & mother=mum & 24 & & \\
\hline \multirow{3}{*}{ Strong-weak } & mother $<$ mum & 13 & \multirow{3}{*}{-2.506} & \multirow{3}{*}{.012} \\
\hline & mother $>$ mum & 32 & & \\
\hline & mother=mum & 29 & & \\
\hline \multirow{3}{*}{ Beautiful-ugly } & mother $<$ mum & 6 & \multirow{3}{*}{-3.876} & \multirow{3}{*}{.000} \\
\hline & mother $>$ mum & 31 & & \\
\hline & mother=mum & 38 & & \\
\hline \multirow{3}{*}{ Far away-close } & mother $<$ mum & 25 & \multirow{3}{*}{-2.184} & \multirow{3}{*}{.029} \\
\hline & mother $>$ mum & 12 & & \\
\hline & mother $=$ mum & 37 & & \\
\hline \multirow{3}{*}{ Bad-good } & mother $<$ mum & 17 & \multirow{3}{*}{-1.628} & \multirow{3}{*}{.103} \\
\hline & mother $>$ mum & 12 & & \\
\hline & mother $=$ mum & 45 & & \\
\hline \multirow{3}{*}{ Clear-unclear } & mother $<$ mum & 17 & \multirow{3}{*}{-0.503} & \multirow{3}{*}{.615} \\
\hline & mother $>$ mum & 19 & & \\
\hline & mother $=$ mum & 38 & & \\
\hline
\end{tabular}

We can notice (Table 2) that participants "experience" the meaning of a word "mum" as more "young" $(\mathrm{z}=-4.096, \mathrm{p}<.001)$, "active" $(\mathrm{z}=-4.348, \mathrm{p}<.001)$, "strong" $(\mathrm{z}=-2.506, \mathrm{p}$ $<.05)$, "beautiful" ( $\mathrm{z}=-3.876, \mathrm{p}<.001)$, and "close" $(\mathrm{z}=-2.184, \mathrm{p}<.05)$ than the meaning of a word "mother". This is the case because we used to call our mother "mum" when we were children and we usually call her "mother" when we are adults. Hence, we confirmed the first hypothesis.

Table 3. The results of comparisons between "home" and "house"

\begin{tabular}{ccccc} 
Pairs of adjectives & Comparisons & Number of ranks & $\mathrm{z}$ & $\mathrm{p}$ \\
\hline \multirow{3}{*}{ Hot-cold } & home $>$ house & 32 & -4.575 & .000 \\
& home $>$ house & 6 & & \\
& home=house & 35 & & \\
\hline \multirow{3}{*}{ Old-young } & home $>$ house & 25 & -0.529 & .597 \\
& home $>$ house & 20 & & \\
\hline
\end{tabular}




\begin{tabular}{|c|c|c|c|c|}
\hline \multirow{3}{*}{ Soft-hard } & home $<$ house & 40 & \multirow{3}{*}{-4.625} & \multirow{3}{*}{.000} \\
\hline & home $>$ house & 7 & & \\
\hline & home $=$ house & 24 & & \\
\hline \multirow{3}{*}{ Active-passive } & home $<$ house & 28 & \multirow{3}{*}{-2.297} & \multirow{3}{*}{.022} \\
\hline & home $>$ house & 13 & & \\
\hline & home $=$ house & 28 & & \\
\hline \multirow{3}{*}{ Big-small } & home $<$ house & 21 & \multirow{3}{*}{-0.046} & \multirow{3}{*}{.964} \\
\hline & home $>$ house & 16 & & \\
\hline & home $=$ house & 32 & & \\
\hline \multirow{3}{*}{ Strong-weak } & home $<$ house & 18 & \multirow{3}{*}{-0.545} & \multirow{3}{*}{.586} \\
\hline & home $>$ house & 16 & & \\
\hline & home $=$ house & 36 & & \\
\hline \multirow{3}{*}{ Beautiful-ugly } & home $<$ house & 29 & \multirow{3}{*}{-3.404} & \multirow{3}{*}{.001} \\
\hline & home $>$ house & 9 & & \\
\hline & home $=$ house & 31 & & \\
\hline \multirow{3}{*}{ Far away-close } & home $<$ house & 15 & \multirow{3}{*}{-2.731} & \multirow{3}{*}{.006} \\
\hline & home $>$ house & 28 & & \\
\hline & home $=$ house & 26 & & \\
\hline \multirow{3}{*}{ Bad-good } & home $<$ house & 9 & \multirow{3}{*}{-1.561} & \multirow{3}{*}{.118} \\
\hline & home $>$ house & 23 & & \\
\hline & home $=$ house & 36 & & \\
\hline \multirow{3}{*}{ Clear-unclear } & home $<$ house & 29 & \multirow{3}{*}{-3.438} & \multirow{3}{*}{.001} \\
\hline & home $>$ house & 11 & & \\
\hline & home $=$ house & 28 & & \\
\hline
\end{tabular}

As can be noticed (Table 3), there is a pattern in respondents' assessments of "home" and "house" emotional tone. They perceived "home" as hotter $(\mathrm{z}=-4.575, \mathrm{p}<.001)$, softer $(\mathrm{z}=-4.625, \mathrm{p}<.001)$, more active $(\mathrm{z}=-2.297, \mathrm{p}<.05)$, more beautiful $(\mathrm{z}=-3.404, \mathrm{p}<$ $.01)$, closer $(\mathrm{z}=-2.731, \mathrm{p}<.01)$, and more clear $(\mathrm{z}=-3.438, \mathrm{p}<.01)$. This results was expected, because the word "home" sounds more intimate and is related to the place where our family lived. On the other side, a word "house" sounds like a material object (e.g. just like building, apartment or similar thing). Therefore, the second hypothesis was confirmed, too.

Table 4. The results of comparisons between "person" and "man"

\begin{tabular}{ccccc} 
Pairs of adjectives & Comparisons & Number of ranks & $\mathrm{z}$ & $\mathrm{p}$ \\
\hline \multirow{3}{*}{ Hot-cold } & man< person & 28 & & \\
& man>person & 29 & -0.336 & .737 \\
& man=person & 17 & & \\
\hline
\end{tabular}




\begin{tabular}{|c|c|c|c|c|}
\hline \multirow{3}{*}{ Old-young } & man $<$ person & 13 & \multirow{3}{*}{-3.702} & \multirow{3}{*}{.000} \\
\hline & man $>$ person & 33 & & \\
\hline & $\operatorname{man}=$ person & 26 & & \\
\hline \multirow{3}{*}{ Soft-hard } & $\operatorname{man}<$ person & 19 & \multirow{3}{*}{-1.952} & \multirow{3}{*}{.051} \\
\hline & man $>$ person & 34 & & \\
\hline & man $=$ person & 18 & & \\
\hline \multirow{3}{*}{ Active-passive } & $\operatorname{man}<$ person & 27 & \multirow{3}{*}{-0.785} & \multirow{3}{*}{.433} \\
\hline & man $>$ person & 16 & & \\
\hline & $\operatorname{man}=$ person & 29 & & \\
\hline \multirow{3}{*}{ Big-small } & $\operatorname{man}<$ person & 41 & \multirow{3}{*}{-3.992} & \multirow{3}{*}{.000} \\
\hline & man $>$ person & 11 & & \\
\hline & $\operatorname{man}=$ person & 22 & & \\
\hline \multirow{3}{*}{ Strong-weak } & $\operatorname{man}<$ person & 40 & \multirow{3}{*}{-4.134} & \multirow{3}{*}{.000} \\
\hline & man $>$ person & 7 & & \\
\hline & man=person & 25 & & \\
\hline \multirow{3}{*}{ Beautiful-ugly } & $\operatorname{man}<$ person & 33 & \multirow{3}{*}{-1.264} & \multirow{3}{*}{.206} \\
\hline & man $>$ person & 19 & & \\
\hline & man=person & 18 & & \\
\hline \multirow{3}{*}{ Far away-close } & $\operatorname{man}<$ person & 29 & \multirow{3}{*}{-0.297} & \multirow{3}{*}{.767} \\
\hline & man $>$ person & 26 & & \\
\hline & $\operatorname{man}=$ person & 16 & & \\
\hline \multirow{3}{*}{ Bad-good } & $\operatorname{man}<$ person & 14 & \multirow{3}{*}{-3.645} & \multirow{3}{*}{0,000} \\
\hline & man $>$ person & 35 & & \\
\hline & $\operatorname{man}=$ person & 22 & & \\
\hline \multirow{3}{*}{ Clear-unclear } & $\operatorname{man}<$ person & 37 & \multirow{3}{*}{-3.602} & \multirow{3}{*}{0,009} \\
\hline & man $>$ person & 16 & & \\
\hline & $\operatorname{man}=$ person & 19 & & \\
\hline
\end{tabular}

With respect to the data shown in Table 4, we can conclude that participants perceive "man" as younger $(\mathrm{z}=-3.702, \mathrm{p}<.001)$, bigger $(\mathrm{z}=-3.992, \mathrm{p}<.001)$, stronger $(\mathrm{z}=4.134$, $\mathrm{p}<.001)$, better $(\mathrm{z}=-3.645, \mathrm{p}<.001)$, and more clear $(\mathrm{z}=-3.602, \mathrm{p}<.01)$ than "person". It seems that our respondents gave their answers regarding the stereotype of a strong, big and young man. A person can be a women, too. But the word "man" produces clear associations which are more related to strength, height, and other positive physical characteristics. Based on this findings, we can say that we confirmed our last hypothesis.

\section{Discussion}

As we stated before, all hypotheses were confirmed. Superficially looking at these three pairs of words (or terms), we can falsely conclude that they mean the same thing. The word "mum" is a synonym for "mother", the word "home" is a synonym for "house", and the 
word "man" can be seen as a synonym for "person". However, if we dig deeper, we will realize that those pairs of words refer to slightly different emotions, mental representations, and mental images.

We found that the word "mum" is perceived as "younger", "stronger", more "beautiful", more "close", and more "active" than the word "mother". The denotative meaning of "mother" is "female parent", whereas the word "mum" comprises: love, care, emotions, protection, and support.

We also found that the word "home" has different meaning compared to the word "house". Home is a safe place, where family gathers, and where we experience positive atmosphere, sincere emotions, and a sense of belonging. On the other side, house is a type of a place of residence.

In the end, we compared the word "man" with the word "person". A person can be a male or a female and this term is more general than the term "man". Men are considered as strong and taller/bigger than women. Therefore, if someone imagines a person, it is more abstract and more unclear concept than "man". In contrast, if we imagine a man, we have an image of a male person who has particular physical traits (such as stamina, muscles, paternal characteristics, etc.).

In our semantic differential form, we mostly used the adjectives which were used by other researchers (e.g. Gargante et al., 2013:9; Keller et al., 2013:71; Norbergh et al., 2006:264; Havelka, Kuzmanovic, \& Popadic, 2008:220; Weed \& Nicholson, 2014:1). We added some new pairs of adjectives as well. Our results are consistent with the results of other researchers because semantic differential seemed to be a very good and useful tool for determining tiny differences in connotative meanings.

We cannot make comparisons between our and others' results in a domain-specific topics, because, as we said before, there are no the real empirical studies in linguistics concerning emotional tone of pairs of synonyms.

\section{Conclusion}

In accordance to the literature review and proposed hypothesis, we can conclude several things. First, the semanitc differential technique is a widely applicable tool, especially in cognitive linguistics and semantics. It can also be applied in social psychology, educational science, personality psychology, sociology, etc. This fact was underlined by Osgood et al. (1957:342), Snider and Osgood (1969:55), Havelka et al. (2008:220), and Norbergh et al. (2006:264).

Second, the semantic differential can help us to examine some nuances in meaning space (the so-called semantic space) of words with similar meaning. We did it in our study, which was also done by Keller et al. (2013:71). We compared three pairs of similar words, whereas these authors compared the word "spirituality" with the word "religion".

Third, semantic spaces of our pairs of words are not the same. They differ in their emotional tone (i.e. they "sound" slightly different). There were statistically sigtnificant differences between the words "mum" and "mother" in the following pairs of adjectives: young - old, active - passive, strong - weak, beautiful - ugly, and far away - close. That is, the word "mum" carries more positive connotations than the word "mother". Next, we found statistically significant differences between the words "home" and "house". These differences were present in the following pairs of adjectives: hot - cold, soft - hard, active - passive, beautiful - ugly, far away - close, and clear - unclear (obscure). The word 
"home" was estimated more positively than the word "house". Lastly, there were also significant differences in perceiving the words "man" and "person". These differences are detected in five pairs of adjectives: old - young, big - small, strong - weak, good - bad, and clear - unclear (obscure). In particular, participants consider the word "man" stronger, bigger, younger and better than the word "person".

Hence, some words predominantly refer to their denotative meaning whereas other words activate various connotative meanings, which are also a part of our mental schemes and representations. We learn and memorize words by ascribing them different meanings. Some of these meanings are semantically proximal (denotations), while the others are more distal (connotations).

\section{References}

BARTHES, R., LAVERS, A., SMITH, C. (1967). Elements of Semiology. New York: Hill and Wang, $111 \mathrm{pp}$.

CRYSTAL, D. (1987). The Cambridge Encyclopedia of Language. Cambridge: Cambridge University Press, 480 pp.

GARGANTE, A. B., MENESES, J., MONEREO, C. (2013). Affective dimension of university professors about their teaching: An exploration through the semantic differential technique. Univ. Psychol., 13(1), pp. 161-173.

GARLAND, R. (1990). A comparison of three forms of the semantic differential. Marketing Bulletin, 1, pp. 19-24.

HAVELKA, N., KUZMANOVIC, B., POPADIC, D. (2008). Metode i tehnike socijalnopsiholoških istraživanja [Methods and techniques of the sociopsychological studies]. Beograd: CPP, 256 pp.

KELlER, B., KLEIN, C., SWHAJOR, A., SILVER, C.F., HOOD, R.W., STREIB, H. (2013). The semantics of "spirituality" and related self-identifications: A comparative study in Germany and the USA. Archive for the Psychology of Religion, 35(1), pp. 71-100.

LARSON, M. L. (1984). Meaning-Based Translation. Landham, Maryland: University Press of America, $537 \mathrm{pp}$.

NORBERGH, K. G., HELIN, Y., DAHL, A., HELLZEN, O., ASPLUND, K. (2006). Nurses' attitudes towards people with dementia: The semantic differential technique. Nursing Ethics, 13(3), pp. 264-274.

OSGOOD, C. E., SUCI, G. J., TANNENBAUM, P. H. (1957). The measurement of meaning. Champaign, IL: University of Illinois Press, $342 \mathrm{pp}$.

SNIDER, J. G., OSGOOD, C. E. (1969). Semantic differential technique: A sourcebook. Chicago: Aldine, $681 \mathrm{pp}$. 640 pp.

STERNBERG, R. (2012). Cognitive psychology (6th ed.). Belmont, CA: Wadsworth,

WEED, K., NICHOLSON, J. S. (2014). Differential social evaluation of pregnant teens, teen mothers and teen fathers by university students. Int J Adolesc Youth, 20, pp. 116. 